\title{
Fatherhood in Men Who Underwent Bariatric Surgery in Campina Grande Paraíba, Brazil
}

\author{
Camilla Ribeiro Lima de Farias MSc ${ }^{1}$, Kalyanne Mayara Luna Alves², Carlos Teixeira Brandt MD, PhD ${ }^{3 *}$
}

${ }^{1}$ Lecturer, Public Health Science, Universidade Estadual da Paraíba (UEPB), Unifacisa, Brazil.

${ }^{2}$ Nurse student, Medical School, Unifacisa, Brazil.

${ }^{3}$ The University of Liverpool, UK, Scientific Director, Unifacisa, Brazil.

*Corresponding author: Carlos Teixeira Brandt, The University of Liverpool, UK, Scientific Director, Unifacisa, Brazil.

Received date: March 16, 2021: Accepted date: July 27, 2021: Published date: August 02, 2021

Citation: C R L Farias, K M L Alves, Carlos T Brandt. (2021). Fatherhood in Men Who Underwent Bariatric Surgery in Campina Grande Paraíba, Brazil. Journal of Clinical Surgery and Research. 2(4); DOI: 10.31579/2768-2757/008

Copyright: (92021 Carlos Teixeira Brandt, This is an open-access article distributed under the terms of the Creative Commons Attribution License, which permits unrestricted use, distribution, and reproduction in any medium, provided the original author and source are credited.

\begin{abstract}
Sexual functioning is an important, yet often overlooked, aspect of life quality for many individuals with obesity, especially regarding to man. Fertility and sperm quality are even less explored in the scientific literature. To the best of our knowledge, there is no report of man being a father after bariatric surgery. Here, we report a four men recruited from a prospective cohort of individuals, from both gender, who underwent bariatric surgery in the past three years. The total sample was 192 (146 women $76.0 \%$ and 46 men $-24.0 \%$ ). From the 46 men, $4(8.7 \%)$ became father of six normal offspring. The ages of the men were respectively: $34 ; 38 ; 41$; and 43 years of age. These patients were married. The post bariatric surgery pregnancies, from the same spouses before surgical procedures, were without any abnormalities and the newborns presented no congenital anomalies. These individuals referred increased sexual desire after surgery and improvement of erectile function. This case series reported highlights the contribution of bariatric surgery in the sexuality, fertility and fatherhood of obese man.
\end{abstract}

Keywords: obesity; sexual dysfunction; fertility; bariatric surgery; man

\section{Introduction}

Sexuality is an important element of quality of life in human being. In the context of chronic diseases, such as obesity, this multidimensional construct can be seen under the umbrella of quality of life [1-3].

Bariatric surgery has been the main treatment for obese patients when clinical attempts fail in controlling the body mass index (BMI) and morbidities associated with this condition [4-7].

Among the clinical implications of obesity, sexuality and fertility are less explored in scientific research regarding to indication for bariatric surgery, as well as the outcome of this important aspect of life quality [8$10]$.

There is increasing evidence that male obesity reduces sperm quality regarding physical and molecular structure of germ cells in the testes. Thus, limiting fertility and the ability of fatherhood $[11,12]$.

The purpose of this case series report is to document four men who underwent bariatric surgery and developed fatherhood.

\section{Case Series Report}

The first case is a brown 38 year-old married man with BMI of 47 who underwent bypass bariatric surgery and became free of type 2 diabetes and blood hypertension in the post-operative follow-up. He also improved his sexual desire and intercourse frequency in the prior four weeks before clinical sexuality evaluation. His present BMI is 29 . The fatherhood was effective, with the same spouse, one year of post-operative follow-up. The mother pregnancy was without complications and the male newborn was healthy. He also became a father of a second female newborn who presented no congenital anomalies. The gestational ages were respectively 37 and 38 weeks and weights were $2.9 \mathrm{Kg} 3.0 \mathrm{Kg}$.

The second case is a brown 26 year-old married man with BMI of 50 who underwent sleeve bariatric surgery and became free of type 2 diabetes and blood hypertension in the post-operative follow-up. He improved his sexual desire and marginally his intercourse frequency in the four weeks before clinical sexuality evaluation. His present BMI is 44. The fatherhood was effective, with the same spouse, five years after surgery. The mother pregnancy was without complications and the newborn was healthy. Nowadays, this young man is regaining weight and looking forward to redo the bariatric surgery procedure.

The third case is a white 42 year-old married man with BMI of 48 who underwent sleeve bariatric surgery and became free of blood hypertension in the post-operative follow-up. He improved his sexual desire and maintained his intercourse frequency in the four weeks before sexuality evaluation. His present BMI is 36. The fatherhood was effective, with the 
same spouse, four years after surgery. The mother pregnancy was without complications. Gestational age was 38 weeks and the female newborn was healthy, with birth weight around $3.15 \mathrm{Kg}$ and Apgar score at 3 minutes was 10 .

The fourth case is awhite 44 year-old man with BMI of 42 who underwent bypass bariatric surgery and became free of blood hypertension in the post-operative follow-up. He marginally improved his sexual desire and intercourse frequency in the four week before clinical sexuality evaluation. His present BMI is 30 . The fatherhood, with the same spouse, was effective four years after surgery. The mother pregnancy was without complication and the newborn was healthy. He also had a second healthy newborn.

\section{Comments}

Infertility and sub-fertility is a frequent clinical finding in obese man, which is proved by reduced sperm concentration, however sperm motility is not yet been proved without any doubt [11]. Additionally, interventions in obese adolescents need to be undertaken carried for through young adulthood aiming at likelihood of being parents [13]. On the other hand, sexual hormones and erectile function are improved in obese men after bariatric surgery after one year follow-up [9]. However, in summary, to the best of our knowledge fatherhood has not yet been reported in the literature.

There are evidence that scrotal obesity impairs spermatogenesis and consequently the likelihood of being a father in obese men. The mechanism for this is related to increased heat in the scrotal pouch, hormonal changes or molecular damage in the germ cell DNA [11]. Bariatric surgery, reducing BMI can, besides restoration of gonadal hormone levels, better control the temperature in the testis environment and also creating the conditions for improvement in the number and quality of spermatozoids offering improvement in the likelihood of fatherhood. This hypothesis is quite likely for explaining the fatherhood of these four young obese men who underwent bariatric surgery. However, this explanation is controversial and tends to be true after some years (two years) post operatively [14, 15].

It is important to report that none of these four young obese men had had babies before undergoing bariatric surgery. The presumption is that bariatric surgery improved male hormones, sexuality and the ability of fatherhood. Additionally, although obesity is associated with damage of sperm, nature has provided ways of preserving reservoir of germ cells to maintain human being specie.

Other consideration worthwhile to report is that in the Northeastern region of Brazil, parents are willing to have large family and the average children per family is greater than the Southern and Southeastern of this country, and impairment of fatherhood due to obesity can be one of the reasons for these patients undergoing bariatric surgery. Thus, this surgical procedure is also beneficial to this human construct.

\section{References}

1. Sarwer DB, Steffen KJ. (2015). Quality of life, body image andsexual functioning in bariatric surgery patients. Eur Eat Disord Rev. 23(6):504-508.
2. Kristine J. Steffen, Wendy C. King, Gretchen E. White, Leslee L. Subak, James E. Mitchell, Anita P. Courcoulas, David R. Flum, Gladys Strain, David B. Sarwer, Ronette L. Kolotkin, Walter Pories, Alison J. Huang. (2019). Changes in sexual functioning in women and men in the 5 years after bariatric surgery. JAMA Surg. 154(6):487-498.

3. Menke MN, King WC, White GE, Gosman GG, Courcoulas AP, Dakin GF, Flum DR, Orcutt MJ, Alfons Pomp, Pories WJ, Purnell JQ, Steffen KJ, Wolfe BM, Yanovski SZ. (2017). Contraception and conception after bariatric surgery. Obstet Gynecol. 130(5): 979-987.

4. Wolfe BM, Kvach E, Eckel RH. Treatment of obesity: weight loss and bariatric surgery. Circ Res. 2016; 118(11): 1844-1855.

5. Martin WP, Docherty NG, Roux CW. (2018). Impact of bariatric surgery on cardiovascular and renal complications of diabetes: a focus on clinical outcomes and putative mechanisms. Expert Rev Endocrinol Metab. 13(5): 251-262.

6. Smith ED, Layden BT, Hassan C, Sanchez-Johnsen L. (2018). Surgical treatment of obesity in Latinos and African Americans: Future directions and recommendations to reduce disparities in bariatric surgery. Bariatr Surg Pract Patient Care. 13(1):2-11.

7. Sarwer DB, Heinberg LJ. (2020). A Review of the psychosocial aspects of clinically severe obesity and bariatric surgery. Am Psychol. 75(2): 252-264.

8. Sarwer DB, Hanson AJ, Voeller J, Steffen K. (2018). Obesity and sexual functioning. Curr Obes Rep. 7(4): 301-307.

9. Moxthe LC, Sauls R, Ruiz M, Marilyn Stern, Gonzalvo J, Gray HL. (2020). Effects of Bariatric Surgeries on Male and Female Fertility: A Systematic Review; J Reprod Infertil. 21(2): 71-86.

10. Bellastella G, Menafra D, Puliani G, Colao A, Savastano S. (2019). On behalf of Obesity Programs of nutrition, Education, Research and Assessment (OPERA) Group. How much does obesity affect the male reproductive function?Int J Obes Suppl. 9(1): 50-64.

11. Palmer NO, Bakos HW, Fullston T, Lane M. (2012). Impact of obesity on male fertility, sperm function and molecular composition. Spermatogenesis. 2(4): 253-263.

12. Sultan S, Patel AG, El-Hassani S, Whitelaw B, Leca BM, Vincent RP, Le Roux CW, Rubino F, Aywlin SJB, Dimitriadis GK. (2020). Male obesity associated gonadal dysfunction and the role of bariatric surgery. Front Endocrinol (Lausane). 11:408.

13. Garfield CF, Duncan G, Gutina A, Rutsohn J, McDade TW, Adam EK, Coley RL, Chase-Lansdale PL. (2016). Longitudinal study of body mass index in young males and the transition to fatherhood. Am J Mens Health. 10(6):158-167.

14. Sermondade N, Massin N, Boitrelle F, Pfeffer J, Eustache F, Sifer C, Czernichow S, Lévy R. (2012). Sperm parameters and male fertility after bariatric surgery: three case series. Reprod Biomed Online. 24(2):206-210.

15. Reis LO, Dias FGF. (2012). Male fertility, obesity, and bariatric surgery. Reprod Sci. 19(8):778-785. 